\title{
Traditional use of ethnomedicinal native plants in the Kingdom of Saudi Arabia
}

\author{
Hanan Aati', Ali El-Gamal ${ }^{1,2}$, Hamdy Shaheen $^{3}$ and Oliver Kayser ${ }^{4 *}$ (D)
}

\begin{abstract}
The Arabian Peninsula is recognized as an arid area dominated by deserts and poor biodiversity. However, the Kingdom of Saudi Arabia (henceforth abbreviated into KSA) has a wide range of flora, consisting of different species of trees, herbs, and shrubs and containing numerous edible and medicinal plants. The KSA is characterized by its vast area of diverse geographical landscapes and climates. Consequently, there is enormous variation in the distribution of plants across the Kingdom. The traditional use of ethnomedical plants in the KSA represents a strong interconnection among familiar remedies, health, diet, and traditional healing practices characterized by specific cultures.

The present paper reviews a collection of medicinal plants in KSA used in ethnomedicine. This review might be useful in developing strategies for the sustainable use of medicinal plants which are among the threatened important natural resources in folk medicine in the KSA. The present study reports 309 genera which cover 471 species from a total of 2253 known species belonging to 89 families. The most dominating families are Asteraceae, Fabaceae, Lamiaceae, Euphorbiaceae, Solanaceae, Apiaceae, Brassicaceae, Chenopodiaceae, Poaceae, Amaranthaceae, Boraginaceae, Apocynaceae, Convolvoulaceae, Asclepiadaceae, Capparaceae, Polygonaceae, and Zygophyllaceae.
\end{abstract}

Keywords: Medicinal plants, Saudi Arabia, Ethnomedicine, Traditional use, Folk medicine, Threatened natural resources

\section{Background}

Plant diversity plays a vital role in serving the ecosystems and in maintaining and preserving ecological balance and stability not only in KSA but also in the whole world as well. Different plant species have been used in ethnomedicine since ancient times [1,2]. Medicines of the Egyptians (3000 BC; pharaohs), the Greeks (400 BC; Hippocrates), and the Romans (37 BC.; Dioscorides) have a longstanding history. The continuous use of plants in therapy was conducted by Prophet Mohammad (peace be upon him, 571-632 AD); a practice known as The Prophetic Medicine (Al- ibb al-Nabawi) by Ibn Qayyim Al-jawziyyah [3]. This period is considered as the golden age for ethnomedicine genesis. The Muslims did not stop at that point, but developed different schools, including the Rhazes (865-925 AD) and Avicenna (980-1037 AD), and their encyclopedias on ethnomedicine The Container Book in Medicine (Kitab Al-Hawi Fi Al-Tibb) and The Law in Medicine (Al-Qanun Fi Al-Tibb), respectively, all of which contributed to

\footnotetext{
* Correspondence: oliver.kayser@tu-dortmund.de

${ }^{4}$ Technical Biochemistry, TU Dortmund University, Emil-Figge-Strasse 66,

44227 Dortmund, Germany

Full list of author information is available at the end of the article
}

the development of herbal medicine $[4,5]$. Several medications have been extracted from natural resources, including plants in the nineteenth century. However, The Prophetic Medicine is still a major reference for all Muslims in the Arabian Peninsula and the rest of the world. Many medicinal plants that have been reportedly used in The Prophetic Medicine are currently used in folk medicine in the Arabian Peninsula. Scientific studies have proven that these plants, including garlic, pomegranate, black seeds, costus, miswak, henna, ginger, and fenugreek are effective for treating human diseases. Such plants have been widely used in the form of low cost and almost zero-side-effect products pharmaceutically manufactured and marketed under such trademarks as Black seed plus, Fenugreek $610 \mathrm{MG}^{\circ}$, Ginkago Biloba Plus TM, Kyolic ${ }^{\circ}$, and Alvita .

The KSA, Kuwait, Bahrain, Yemen, Qatar, United Arab Emirates, and Oman formulate what is known as the Arabian Peninsula which is located in the Asian southwest. Its West and Southwest border is the Red Sea, its southern one is the Gulf of Aden, its southern and southeastern border is the Arabian Sea, and its eastern one is the Gulf of Oman and the Arabian Gulf [6]. Figure 1 highlights the geographical merge of the peninsula with 
the Syrian desert across the northern border, but the northern boundaries of Saudi Arabia and of Kuwait are generally considered as marking the limit of Arabia there.

The 2,250,000 $\mathrm{km}^{2}$ covered by KSA represent the largest part of the Arab Peninsula. Geographically, it is characterized by a variety of habitats including mountains, valleys, lava areas, meadows, and rocky deserts. Therefore, KSA is made up of two areas: the rain fed zones of the western and southwestern highlands and the arid region of the interior area [6].

As for the first division, the Asir highlands constitute a flowing series of cliffs together with similar southwestern highlands, extending far unto the Yemeni borders. They rise up to $2000 \mathrm{~m}$ in some areas (Taif) and over $3000 \mathrm{~m}$ in others (Abha). The same continuity is to be found in the western continuous chain across the Tihama coastal plain. This continuity comes to an end on the northwestern sides where discontinuity dominates. On the other hand, the eastern part comprises a large amount of sand with much lower mountains and plains. These deserts extend to the northern Great Nafud and the southern Rub AlKhali (The Empty Quarter), with Dahna sands connecting both regions. As regards the Central Region, patchy, stone deserts, hillocks, and valleys color the scene versus the complex of metamorphic rocks that characterize the northern and northern central region. Remarkable still is that the altitudes of the plains of the Central Region rise high up to
500-800 m as compared to such mountains and escarpments Jabal Shammar and Jabal Tuwayq which range from 300 to $600 \mathrm{~m}$ [6]. Forests cover 2.7 million hectares (about 1.35\% of the total area) of KSA. Most of the forests are in the southwestern part of the Kingdom on the Sarawat mountain.

With regard to the location of KSA, it is located in a climatic transitional zone of tropical and temperate climates. Moreover, the rains falling upon KSA are neither constant in amount and nor equal in distribution so much that the arid areas right in the interior of KSA underscore no rain in some areas and over $200 \mathrm{~mm}$ in some others on an annual basis. Even in winter, there is rainfall, however irregular.

It is noteworthy that winter in KSA ranges from cool to warm $\left(2-20{ }^{\circ} \mathrm{C}\right)$ as opposed to the high summer temperature ranging from 35 to $50{ }^{\circ} \mathrm{C}$, high humidity along the Red Sea coast and the Arabian Gulf coast; temperature becomes lower right in the interior.

Geographical and climatic diversity in the kingdom lead to the diversity in the flora, examined for the first time in 1974 [7]. This was followed by two volumes of Medicinal Plants of Saudi Arabia that were published in 1987 and 2000 by Mossa et al. [8, 9].

Collenette (1998) asserts that KSA produces about 837 genera manifesting themselves in 2253 species distributed among 132 families. Nearly $20 \%$ of these families stands for totally new and uncommon plants. The southwestern

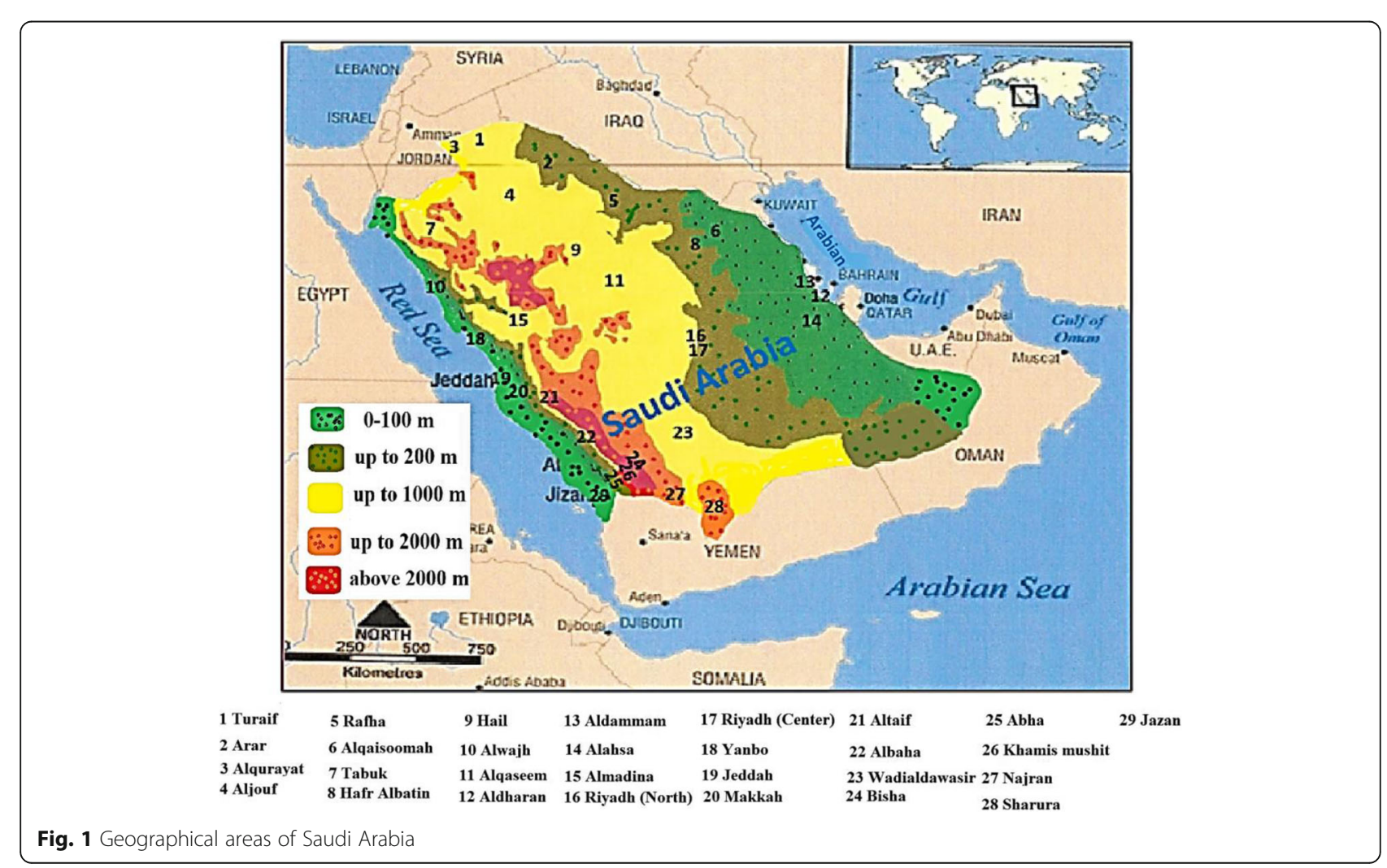


part of KSA embraces about $70 \%$ of the floristic elements grown across Taif to the Yemeni border. This is accounted for the regularity of rainfall upon the region [10].

Equally important is KSA flora provide a remarkably rich source for agriculture and medicinal plants. Although many items of the flora are grown locally and nationally, KSA still grows a curious amalgam of Africa, Asia, and the Mediterranean region.

According to Al-Yahya (1984), employing and resorting to traditional medicine is still a fashionable practice nowadays in KSA [11]. It has become customary for KSA citizens to resort to natural herbs and traditional remedies in the hope that these will certainly heal their illness. Such practices are found in using such natural resources as bee-honey, black seed, myrrh, fenugreek, kawajawa, and among others. It has been to their good fortune that these practices have been handed from one generation to another. Mossa et al. (1987) spotlight the extensive range of flora that covers almost the whole KSA and offers sample opportunity for Saudis to make the best use of herbs and flora for their medications to local individuals for use in and therapeutic practices $[8,9]$.

The KSA is currently implementing an overall plan with a view to regulating and organizing the use of traditional medicine on a national basis. Thus, there is a tendency to legalize what is known as Complementary and Alternative Medicine (TM/CAM) via issuing organizing acts and issuing laws. This has been consolidated by the establishment of the National Office in 1995 on behalf of the Saudi Ministry of Health. Another important step came with the TM/CAM Committee in collaboration with the National Research Institute on herbal medicine studies established by King Saud University Medicinal, Aromatic and Poisonous Plant Research Center (MAPPRC), and the Department of Pharmacognosy, both of the College of Pharmacy.

Historically, these practices in KSA date back to ancient times when using traditional medicine was the only way out for the treatment of many illnesses and diseases that were usually unknown and non-diagnosed. However, these medicines were too much respected as they were prescribed by those traditional healers known as Al-Hokama. It is worthy of notice, however, that such practices are beginning to vanish and pass away. That is why it has become a prerequisite to conduct folk and ethnobotanical surveys and studies in KSA on the vanishing of these practices before they become history. As result, this review can serve as a reference document on traditional uses of medicinal plants in Saudi Arabia and increase the possibility of discovering new drug resources.

\section{Materials and methods}

Journals, textbooks, proceedings, websites, periodicals, and databases dealing with medicinal plants used to treat human diseases in Saudi Arabia, Arabian Peninsula, and other parts of the world were checked for related information. Dictionaries of English/Arabic and Arabic/English were also consulted for accuracy.

\section{Results and discussion}

Literature survey showed that a total of 309 genera containing 471 species in 89 families are used in ethnomedicine (Table 1 and Fig. 2). Asteraceae and Fabaceae families have the highest number of ethnomedicinal species (54 and 49, respectively) in Saudi Arabia. Additional file 1: Table S1 summarizes ethnobotanical data on all medicinal plants used in KSA [12-41].

Table 1 shows numerous plant species used for various illnesses associated with gastrointestinal problems, pains, rheumatism inflammations, ulcers, respiratory, circulatory, urological, and skin diseases, and some for toothache, diabetes, allergy, and gynecology. The most mentioned medicinal plant families were Asteraceae, Fabaceae, Lamiaceae, Euphorbiaceae, Solanaceae, Apiaceae, Brassicaceae, Chenopodiaceae, Poaceae, Amaranthaceae, Boraginaceae, Apocynaceae, Convolvoulaceae, Asclepiadaceae, Capparaceae, Polygonaceae, and Zygophyllaceae. All these families as well as other families mentioned in this review are already represented in Saudi Arabia flora [7, 42].

Resorting to traditional medicinal plants for treating some illnesses has resulted in many the production of many promising drugs and medications [43, 44]. The present paper reviews these practices from an ethnopharmacological perspective by targeting 471 medicinal plants used on a regular basis by almost all Saudis (Additional file 1: Table S1).

According to Ali et al. (2017), these therapeutic practices and use of medicinal plants appear on the Use Index (UI), [UI $=(\mathrm{na} / \mathrm{NA} \times 100)$, where na is the number of questioners who refer to the species as valuable and NA is the total number of people met]. Three vital plants were at the core of Saudis' practices: Juniperus procera, Rumex nervosus, and Ziziphus spina-chris [33]. Therefore, these three important and commonly used plants have been discussed here in detail.

Juniperus procera Hochst. ex Endl is known as "Arar" in KSA. It is a long tree that reaches up to $8 \mathrm{~m}$ tall with needle-shaped leaves, extending from the south reigon of the Arab Peninsula across the Red Sea into Africa [45]. Juniperus is one of the major genera of Cupressaceae family consisting of approximately 70 species [46]. Traditionally in Saudi Arabia, J. procera used for treating hepatic diseases, jaundice, gastrointestinal disturbances, and pharyngitis, as antirheumatism, for gout and several inflammatory conditions $[21,47]$. In ethnomedicine, the resinous material of $J$. procera was added to bee-honey and used as a remedy for curing hepatic and skin diseases [48].

A previous phytochemical study of different parts of J. procera resulted in the isolation of different classes 
Table 1 Number of traditionally used species per family in Saudi Arabia

\begin{tabular}{|c|c|c|c|}
\hline Family name & Number of species in KSA & Family name & Number of species in KSA \\
\hline Acanthaceae & 5 & Lauraceae & 1 \\
\hline Adiantaceae & 1 & Linaceae & 1 \\
\hline Agavaceae & 2 & Lythraceae & 2 \\
\hline Aizoaceae & 4 & Malvaceae & 5 \\
\hline Amaranthaceae & 13 & Meliaceae & 1 \\
\hline Annonaceae & 1 & Menispermaceae & 2 \\
\hline Apiaceae (Umbelliferae) & 18 & Mimosaceae & 1 \\
\hline Apocynaceae & 10 & Moraceae & 4 \\
\hline Aracaceae & 3 & Moringaceae & 1 \\
\hline Aristolochiaceae & 1 & Myrtaceae & 5 \\
\hline Asclepiadaceae & 9 & Nyctaginaceae & 2 \\
\hline Asphodelaceae & 4 & Oleaceae & 2 \\
\hline Asteracea (Compositae) & 54 & Onagraceae & 1 \\
\hline Boraginaceae & 13 & Orobanchaceae & 2 \\
\hline Balanitaceae & 1 & Orchidaceae & 1 \\
\hline Brassicaceae (Cruciferaceae) & 17 & Oxalidaceae & 1 \\
\hline Burseraceae & 5 & Papavaraceae & 3 \\
\hline Cactaceae & 1 & Pedaliaceae & 1 \\
\hline Caesalpinaceae & 1 & Plantaginaceae & 4 \\
\hline Cannabaceae & 1 & Plumbaginaceae & 2 \\
\hline Capparaceae (Capparidaceae) & 8 & Polygonaceae & 8 \\
\hline Caryophyllaceae & 2 & Portulacaceae & 2 \\
\hline Celastraceae & 2 & Primulaceae & 1 \\
\hline Chenopodiaceae & 15 & Punicaceae & 1 \\
\hline Ceratophyllaceae & 1 & Ranunculaceae & 3 \\
\hline Cleomaceae & 6 & Resedaceae & 3 \\
\hline Clusiaceae & 1 & Rhamnaceae & 2 \\
\hline Commelinaceae & 1 & Rosaceae & 4 \\
\hline Convolvoulaceae & 9 & Rubiaceae & 1 \\
\hline Cucurbitaceae & 6 & Rutaceae & 2 \\
\hline Cupressaceae & 2 & Salvadoraceae & 1 \\
\hline Cuscutaceae & 1 & Sapindaceae & 1 \\
\hline Cynomoriaceae & 1 & Sapotaceae & 2 \\
\hline Cyperaceae & 2 & Scrophulariaceae & 2 \\
\hline Ephedraceae & 1 & Solanaceae & 20 \\
\hline Euphorbiaceae & 26 & Tamaricaceae & 3 \\
\hline Fabaceae (Leguminosae) & 49 & Thymelaceae & 1 \\
\hline Frankenaceae & 1 & Tiliaceae & 2 \\
\hline Fumariaceae & 1 & Typhaceae & 1 \\
\hline Geraniaceae & 1 & Urticaceae & 2 \\
\hline Graminae (Poaceae) & 13 & Verbenaceae & 2 \\
\hline Grossulariaceae & 1 & Vitaceae & 2 \\
\hline Iridaceae & 1 & Zingiberaceae & 4 \\
\hline Labiatae (Lamiaceae) & 33 & Zygophyllaceae & 7 \\
\hline Liliaceae & 4 & & \\
\hline
\end{tabular}




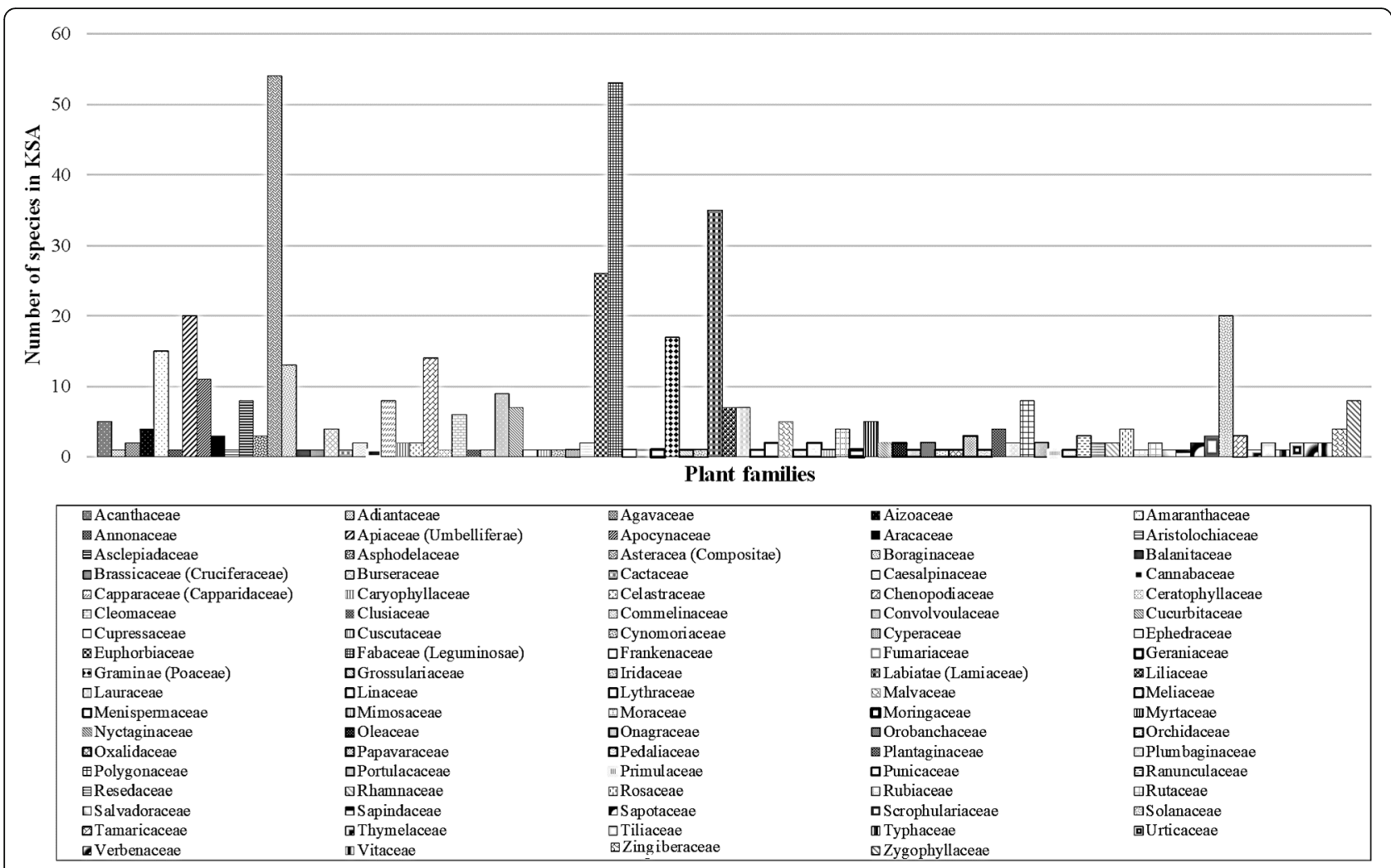

Fig. 2 Number of traditionally used species per family in Saudi Arabia

of sesquiterpenes and diterpenes, where the stem bark of $J$. procera afforded two lignans identified as $\beta$-peltatin and deoxypodophyllotoxin [95]. In addition, the stem barks and leaves of the same plant gave two diterpenes designated as totarol and sugiol with strong antimicrobial activity $[49,50]$. Abietane, pimarane, and labdane types of diterpenes have been isolated from J. procera fruits which showed antiparasitic and nematicidal activities [51]. Moreover, totarol exhibited a synergistic effect with isoniazide (INH) towards four Mycobacterium species [52]. In addition, its essential oil possesses significant antioxidant/free radical scavenging activity [53].

The less polar fraction of the aerial part of J. procera exhibited significant hepatoprotective effect against liver toxicity induced by $\mathrm{CCl}_{4}$. The hepatoprotective activity has been referred to the presence of terpenes in good yield: 4-epi-abietol, ferruginol, hinokiol, sugiol, $Z$-communic acid and hinokiol-1-one, and 3- $\beta$-12-dihydroxyabieta-8,11,13-triene-1-one, in addition to 8 - $\alpha$-acetoxyelemol sesquiterpene [54]. A toxicity study of $J$. procera extract revealed the safety of the extract even at high doses with no acute or chronic toxicity appearance [48]. Additional file 1: Figure S1 shows the structures of the major compounds isolated from $J$. procera.
Rumex nervosus Vahl. is known locally as "Ithrib." Some people in the Arabian Peninsula especially in Yemen and Saudi Arabia consume $R$. nervosus, which makes it an edible plant. However, if eaten in large quantities, it can produce toxic effects because of its high calcium oxalate content [55]. Rumex nervosus belongs to the family Polygonaceae and is a large annual herb that can grow up to $1.5 \mathrm{~m}$ tall, its leaves are usually sagittate, the inflorescence is considerably branched, and it has a leafless panicle. It has a light brown nut, and its fruits are cordate-orbicular. It is widely distributed in Yemen, Saudi Arabia, Ethiopia, Somalia, Kenya, and Tanzania. Ithrib is a very common plant that is used by native people as a diuretic, antipyretic, and antirheumatic and to treat gonorrhea, leprosy, lung tuberculosis, and liver illness; as antihypertensive, antihemorrhoids, antiscabies, antiemetic, aphrodisiac, antitussive, and antirabies; and for dermatitis, antiacne, hypoglycemic, antiinfective, and headache. Decoction of the leaf or root powder produces a substance that is used as a vermifuge. Moreover, the leaves of $R$. nervosus are utilized to treat skin rashes and young leaves are roasted to decrease the acid content before being eaten. The material formed after the burning of the stem is mixed with egg yolk or butter and applied to burns [55-59]. 
There are some reports on the anthelmintic [55], anti-inflammatory and antiviral [57], analgesic [58], diuretic and laxative [59], and antioxidant [60] effects of $R$. nervosus.

It has been confirmed that $R$. nervosus extracts contain alkaloids, flavonoids, phenols, amino acids, furanocoumarins, and saponins by preliminary phytochemical screening [61].

Moreover, the genus Rumex is characterized by the presence of anthraquinones, naphthalene-1,8-diols, flavonoids, and stilbenoids [62]. Many phenolic compounds have been isolated from the $R$. nervosus ethyl acetate fraction, including kaempferol, quercetin, gallic acid, hyperoside, quercetin 3-O-(6" -acetyl)-galactoside, hesperidin, quercetin, $p$-hydroxy benzoic acid, catechol, and pyrogallol [63]. Additional file 1: Figure S2 shows the structures of the major compounds isolated from $R$. nervosus.

Ziziphus spina-christi is commonly called "Jujube" and is locally known as "Sidr" or "Nabuk." It is a multiuse tree belonging to the family Rhamnaceae. Sidr is a native plant that grows in tropical and subtropical regions, and it is widely distributed throughout the Mediterranean regions, Africa, Asia, and tropical America. In Saudi Arabia, Sidr is wildly distributed throughout the southern and southwestern area and has been used as an ornamental plant and for shade. It is a tall tree that can reach $20 \mathrm{~m}$ in height. Its leaves are glabrous on the upper surface, finely pubescent on the lower surface, and ellipsoid or ovate lanceolate in shape with an obtuse or acute apex [64].

Ziziphus spina-christi is greatly respected by Muslims since it is mentioned in the Sunnah and the Holy Quraan twice [65]. From ancient times, in Chinese traditional medicine, suan zao ren (Z. spinosa) has been used to increase blood flow to the heart and liver, and it is used to control irritability, insomnia, and palpitations [66]. In Saudi folk medicine, the leaves of $Z$. spina-christi (jujube) are used to heal wounds, treat some skin diseases and sores, cure ringworm, antipyretic, gonorrhea, sex diseases, some inflammatory conditions, and ulcers. Furthermore, it has been reported that $Z$. spina-christi leaves are used in folk medicine as antidiabetic remedy [67]. In the Bedouin, the decoction of the stem bark and fresh fruits is used as a body rinse, to cure fresh wounds, and is also used for the management of dysentery, bronchitis, coughs, and tuberculosis [68].

Previous phytochemical investigation revealed it contains biologically active secondary metabolites including, tannins, flavonoids, terpernoids, saponin glycosides, and alkaloids [68].

Pharmacological studies have demonstrated that the total alcoholic extract of the current plant leaves and stem bark has showed significant antioxidant, antimicrobial, and antidiarrheal activities [66, 69]. Additionally, the aqueous extract from the root bark has an antinociceptive activity [70] and central nervous system depressant effect in mice [71]. The butanol extract of Z. spina-christi leaves has shown potent hypoglycemic/antidiabetic activities [72]. The aqueous and ethanolic extracts of stem bark of $Z$. spina-christi have been studied, and an anticholinergic effect was observed [73], which proved the traditional use of the plant as antispasmodic. A cytotoxic effect was observed for the aerial part of $Z$. spina-christi against cervical, breast, and colon cancers [66].

A phytochemical study of $Z$. spina-christi indicated the presence of betulic and ceanothic acids [74]. Cyclic peptide alkaloids, franaganine, mauritine $C$, and sativanine A have been isolated and fully characterized from the stem bark of $Z$. spina-christi [75]. Triterpenoidal saponins were recently isolated from the leaves of the same plant and screened for their antidiabetic activity [76]. Additionally, four saponin glucosides identified as christinin A-D have been isolated from the leaves $n$. butanol extract leaves and their structures were fully characterized by using spectroscopic technique [77]. Furthermore, quercetin, hyperoside, ruin, and quercetin-3-O- $[\beta$-xylose-(1-2)- $\alpha$-rhamnose] 4'-O- $\alpha$-rhamnose have also been isolated from the leaves and fruits of Z. spina-christi [78]. Additional file 1: Figure S3 shows the structures of the major compounds isolated from $Z$. spina-christi.

\section{Conclusions}

Ethnomedicinal knowledge is not transferred from the older generations to the young age generations, meaning it will soon be erased especially as most younger individuals prefer to visit clinics and hospitals more regular than older people and the Bedouin. Moreover, folkloric healers (Hakeem) use wild herbs randomly and without any restriction, which increases the chance of extinction of certain medicinal plants. This requires greater consideration because more than 15,000 plant species might face extinction worldwide due to over-harvesting and misuse [2, 14]. Therefore, owing to the high diversity of medicinal plants in the KSA, the present review recommends the following:

- Phytochemical and pharmacological studies on the different flora plants.

- Creation of distribution maps for important medicinal plants using GPS coordinates.

- Data analysis of medicinal plants based on their phytochemical, chemotaxonomical, and pharmacognestical characteristics.

- Monographs of some pharmacopoeial medicinal plants.

- Continuing the surveying of plants and identification of their exact locations.

- Plants provided with sequence bank and fingerprinting.

- Seed library for the plants or seed bank to preserve genetic diversity and to preserve rare plant species. 
A total of 471 plant species belonging to 89 families were recorded in the present review from the KSA, which means that this country has a large number of medicinal plants that need to be discovered and have their chemical and pharmacological properties studied.

The findings from the present review paper lend support to the extensive traditional medicinal knowledge in the KSA, which provide the basis for further medicinal research on a scientific evidence basis.

The current study has reviewed a total of 471 plant species belonging to 89 families grown in KSA. This highlights the vast wealth of medicinal plants in KSA. These plants have been used as medications for healing and treating many diseases on an ethnomedicinal, folk medicinal, and national basis. Practicing traditional medicine by resorting to these plants in KSA dates back to ancient times so that it has become fashionable among almost all Saudis.

Therefore, it is suggested that further studies be conducted on unveiling the pharmaceutical, pharmacological, chemical, and laboratory properties of these medicinal plants that have never been targeted before via studies from this perspective. Thus, this tremendous treasure of medicinal plants in KSA needs a greater deal of attention so that researcher would direct future studies to dig out the undiscovered secrets of these plants from a scientific angle of vision. It is hoped that these future studies, once scientifically conducted, will come up with new discoveries in the form of new drug leads extracted from natural resources that would utterly changes the medication shelves all over the world.

\section{Additional file}

Additional file 1: Table S1. Ethnobotanical information on some medicinal herbs used in different regions of Saudi Arabia. Figure S1. Structures of the major compounds isolated from J. procera. Figure S2. Structures of the major compounds isolated from $R$. nervosus. Figure S3. Structures of the major compounds isolated from Z. spina-christi. (DOCX $771 \mathrm{~kb}$ )

\section{Abbreviations}

KSA: Kingdom of Saudi Arabia; MAPPRC: Medicinal, Aromatic and Poisonous Plant Research Center; TC/CAM: Traditional medicine and/or complementary medicine; UI: Use index

\section{Acknowledgedments}

This research project was supported by a grant from the "Research Center of the Female Scientific and Medical Colleges", Deanship of Scientific Research, King Saud University.

\section{Funding}

This research project was supported by a grant from the "Research Center of the Female Scientific and Medical Colleges," Deanship of Scientific Research, King Saud University.

\section{Availability of data and materials}

This research project was supported by a grant from the "Research Center of the Female Scientific and Medical Colleges," Deanship of Scientific Research, King Saud University.

\section{Authors' contributions}

HA carried literature search, participated in writing and data analysis, helped to draft the manuscript and submitted finally. AG conceived of the study and participated in its design and coordination and helped to draft the manuscript. HS helped to draft the manuscript and corrected the manuscript. OK conceived of the study, and participated in its design and coordination, supervised. All authors read and approved the final manuscript.

Ethics approval and consent to participate

Not applicable

Consent for publication

Not applicable

\section{Competing interests}

The authors declare that they have no competing interests.

\section{Publisher's Note}

Springer Nature remains neutral with regard to jurisdictional claims in published maps and institutional affiliations.

\section{Author details}

'Department of Pharmacognosy, College of Pharmacy, King Saud University, Riyadh 11451, Saudi Arabia. ${ }^{2}$ Department of Pharmacognosy, Faculty of Pharmacy, Mansoura University, El-Mansoura 35516, Egypt. ${ }^{3}$ Department of English, Faculty of Arts, Mansoura University, El-Mansoura 35516, Egypt. ${ }^{4}$ Technical Biochemistry, TU Dortmund University, Emil-Figge-Strasse 66, 44227 Dortmund, Germany.

Received: 16 May 2018 Accepted: 4 October 2018

Published online: 09 January 2019

\section{References}

1. Akgül G, Yılmaz N, Celep A, Celep F, Çakılcıoğlu U. Ethnobotanical purposes of plants sold by herbalists and folk bazaars in the center of Cappadocica (Nevşehir, Turkey). Indian J Tradit Knowle. 2016;15(1):103-8.

2. Polat R, Çakılcıoğlu U, Ulusan MS, Paksoy MY. Survey of wild food plants for human consumption in Elazığ (Turkey). Indian J Tradit Knowle. 2015;1(1):69-75.

3. Abdulkhaliq A, Al Azhari A, Al-Oqdah M. The prophetic medicine for lbn Qayyim Al-jawziyyah. 1st ed. Syria: Arabic Books Revival House Publisher; 1957.

4. Ketab al-hawi fil-țebb, 23 parts in 25 vols., Hyderabad, Deccan, 1374-93/ 1955-73; tr. Faraj b. SALEM (Farraguth) as Continens, ed. Jacobus Britannicus Brixianus, as Liber el-Hauy.i: continent in medicine que composit Bubikir Zacharie Errish filius 2 vols., Brescia, 1486.

5. Avicenna, Ibn Sina; Laleh Bakhtiar (1025). (2nd ed.). New York, NY: AMS Press, Inc. ISBN 0-404-11231-5. http://sekretariat.beacukai.go.id/data/aplikasi/ Buku/lbn\%20Sina/Canon\%20of\%20Medicine\%20Book\%201.pdf.

6. Schultz E, Whitney JW. Vegetation in north-central Saudi Arabia. Jour Arid Environ. 1986;10:175-86.

7. Alfarhan AH, Chaudhary SA, Thomas J. Notes on the flora of Saudi Arabia, 3rd edition. J King Saud Univ. 1998;10(1):31-40.

8. Mossa JS, Al-Yahya MA, Al-Meshal IA. Medicinal plants of Saudi Arabia, vol. I. Riyadh: King Saud University Press; 1987.

9. Mossa JS, Al-Yahya MA, Al-Meshal IA. Medicinal plants of Saudi Arabia, vol. II. Riyadh: King Saud University Press; 2000.

10. Collenette S. Checklist of botanical species in Saudi Arabia. West Sussex: International Asclepiad Society; 1998. p. 78.

11. Al-Yahya MA. Kuwait: Proc III Int Conf Islamic medicine; 1984. p. 349

12. Youssef RSA. Medicinal and non-medicinal uses of some plants found in the middle region of Saudi Arabia. J Med Plants Res. 2013;7(34):2501-13.

13. Al-Sodany YM, Bazaid SA, Mosallam HA. Medicinal plants in Saudi Arabia: I. Sarrwat Mountains at Taif, KSA. Acad J Plant Sci. 2013:6(4):134-45.

14. El-Ghazali GE, Al-Khalifa KS, Saleem GA, Abdallah EM. Traditional medicinal plants indigenous to Al-Rass province, Saudi Arabia. J Med Plants Res. 2010; 4(24):2680-3.

15. El-Shabasy A. Survey on medicinal plants in the flora of Jizan region, Saudi Arabia. Int J Bot Stud. 2016;2(1):38-59.

16. Abulafatih HA. Medicinal plants in southwestern Saudi Arabia. Econ Bot. 1987;41(3):354-60 
17. Al-asmari A, Manthiri RA, Abdo N, AL-duaiji FA, Khan HA. Saudi medicinal plants for the treatment of scorpion sting envenomation. Saudi J Biol Sci. 2017;24:1204-11

18. Vanessa Y, Francisco G, Croft SL. Study of the in vitro antiplasmodial, antileishmanial and antitrypanosomal activities of medicinal plants from Saudi Arabia. Molecules. 2007;17(10):11379-90.

19. Akbar S, Al-Yahya MA. Screening of Saudi plants for phytoconstituents, pharmacological and antimicrobial properties. Aus J Med Herbalism. 2011; 23(2):76-87.

20. Saganuwan AS. Some medicinal plants of Arabian Pennisula. J Med Plant Res. 2010;4(9):766-88.

21. Shahina AZ. Handbook of Arabian medicinal plants. Boca Raton, FloridaLondon-Tokyo: CRC Press; 1994

22. Abed KF. Antimicrobial activity of essential oils of some medicinal plants from Saudi Arabia. Saudi J Biol Sci. 2007;14:53-60.

23. Ahsan SK, Shah AH, Tanira MOM, Ahmad MS, Tariq M, Ageel AM. Studies on some herbal drugs used against kidney stones in Saudi folk medicine. Fitoterapia. 1990;61(5):435-8.

24. Al-Musayeib NM, Mothana RA, Al-Massarani S, Matheeussen A, Cos P, Maes L. Study of the in vitro antiplasmodial, antileishmanial and antitrypanosomal activities of medicinal plants from Saudi Arabia. Molecules. 2012;17:11379-90.

25. Mothana RA, Al-Musayeib NA, Al-Ajmi MF, PaulCos, Maes L. Evaluation of the in vitro antiplasmodial, antileishmanial, and antitrypanosomal activity of medicinal plants used in Saudi and Yemeni traditional medicine. Evid-Based Complement Alternat Med. 2014;24963330:1-7.

26. Al-said MS. Traditional medicinal plants of Saudi Arabia. Am J Chinese Med. 1993;21:291-8.

27. Yaseen M, Bahaffi S, Kigoshi H, Kita M. Pharmacological screening of medicinal plants for anticancer, anti-inflammatory and antidiabetic activities. Planta Med. 2012:78:362

28. Abdallah EM, El-Ghazali G. Screening for antimicrobial activity of some plants from Saudi folk medicine. Global J Res Med Plants Indigen Med. 2013;2(4):210-8.

29. Rahmy TR, El-Ridi MR. Action of Anastatica hierochuntica plant extract on Islets of Langerhans in normal and diabetic rats. Egypt J Biol. 2002;4:87-94

30. Aly MM, Bafeel SO. Screening for antifungal activities of some medicinal plants used traditionally in Saudi Arabia. J Appl Anim Res. 2010;38:39-44.

31. Al-qahtani SN, Alkholy SO, Ferreira MP. Antidiabetic and anticancer potential of native medicinal plants from Saudi Arabia. Polyphenols in Human Health and Disease. London: Elsevier Inc; 2014. 119 - 132

32. Al-Marby A, Ejike CECC, Nasim MJ, Awadh-Ali NA, Al-badani RA, Alghamdi GMA, Claus J. Nematicidal and antimicrobial activities of methanol extracts of 17 plants, of importance in ethnopharmacology, obtained from the Arabian Peninsula. J Intercult Ethnopharmacol. 2016:5(2):114-21.

33. Ali NAA, Al Sokari SS, Gushash A, Anwar S, Al-Karani K, Al-Khulaidi A. Ethnopharmacological survey of medicinal plants in Albaha region, Saudi Arabia. Pharmacognosy Res. 2017;9(4):401-40.

34. Al-Shanwani M. Plants used in Saudi folk medicine. Riyadh: King Abdul Aziz City for Science and Technology; 1996.

35. Rahman MA, Mossa JS, Fahad FMA. Notes on succulent plant species of Saudi Arabia. Bangladesh J Plant Taxon. 2002;9(1):25.

36. Ljubuncic P, Azaizeh H, Portnaya CU, Said O, Saleh K, Bomzon A Antioxidant activity and cytotoxicity of eight plants used in traditional Arab medicine in Israel. J Ethnopharmacol. 2005;99:43-7.

37. Miier AG, Morris M. Plants of Dhofar, the southern region of Oman. Traditional economic and medicinal uses. The office of the Advisor for Conservation of the Environment, Diwan of Royal Court, Sulttanate of Oman; 1989.

38. Al-Rehaily AJ, Al-Said MS, Al-Yahya MA, Mossa JS, Rafatullah S. Ethnopharmacological studies on allspice (Pimenta dioica) in laboratory animals. Pharm Biol. 2002;40:200-5.

39. Ali BH, Bashir AK, Rasheed RA. Effect of traditional medicine plants Rhazya stricta, Bal-anitis aegyptiaca and Haplophylum tuberculatum on paracetamolinduced hepatotoxicity in mice. Phytother Res. 2001;15:598-603.

40. AL-sokari SS, Ali NAA, Monzote L, Al-fatimi MA. Evaluation of antileshmanial activity of Al-baha medicinal plants against Leshmania amazonensis. BioMed Res Int. 2015;938747:1-6.

41. Alamri SA, Moustafa MF. Antimicrobial properties of 3 medicinal plants from Saudi Arabia against some clinical isolates of bacteria. Saudi Med J. 2012;33(3):272-7.

42. Migahid AM. Flora of Saudi Arabia, vol. I. 2nd ed. Riyadh: Riyadh University Publication; 1978
43. Balunas MJ, Kinghorn AD. Drug discovery from medicinal plants. Life Sci. 2005;78:431-41

44. Hostettmann K, Marston A, Ndjoko K, Wolfender JL. The potential of African plants as a source of drugs. Curr Organic Chem. 2000:4:973-1010.

45. Collenette S. Wild flowers of Saudi Arabia. Norwich: East Anglian Engraving Co. Ltd; 1999.

46. Samaha HAM, Ali NAA, Mansi I, Abu-El-Halawa R. Antimicrobial, antiradical and xanthine oxidase inhibitory activities of Juniperus procera plant extracts from Albaha. World J Pharmacy Pharm Sci. 2017;6(2):232-42.

47. Gushash A. Plants in mountains of Sarah and Alhajaz. Albaha: Albaha University Publisher; 2012. p. 7.

48. Alqasoumi SI. Isolation and chemical structure elucidation of hepatoprotective constituents from plants used in traditional medicine in Saudi Arabia. Riyadh: College of Pharmacy, King Saud University; 2007.

49. Muhammad I, Mossa JS, Al-Yahya MA, Ramadan AF, El-Feraly FS. Further antibacterial diterpenes from the bark and leaves of Juniperus procera Hochst. ex Endl. Phytother Res. 1995;9:584-8.

50. Muhammad I, Mossa JS, El-Feraly FS. Additional antibacterial diterpenes from the bark of Juniperus procera. Phytother Res. 1996;10:604-7.

51. Samoylenko V, Dunbar DC, Gafur MDA, Khan SI, Ross SA, Mossa JS, El-Feraly FS, Tekwani BL, Bosselaers J, Muhammad I. Antiparasitic, nematicidal and antifouling constituents from Juniperus berries. Phytother Res. 2008;22:1570-6.

52. Mossa JS, El-Feraly FS, Muhammad I. Antimycobacterial constituents from Juniperus procera, Ferula communis and Plumbago zeylanica and their in vitro synergistic activity with isonicotinic acid hydrazide. Phytother Res. 2004;18:934-7.

53. Burits M, Asres K, Bucar F. The antioxidant activity of the essential oils of Artemisia afra. Artemisia abyssinica and Juniperus procera. Phytother Res. 2001;15:103-8

54. Alqasoumi SI, Abdel-Kader MS. Terpenoids from Juniperus procera with hepatoprotective activity. Pak J Pharm Sci. 2012;25(2):315-22.

55. Raju NJ, Yesuf EA. Evaluation of anthelmintic activities of Rumex abyssinicus Jacq and Rumex nervosus vahl. (polygonaceae). Int J Pharm Sci Rev Res. 2010;5(2):55-7.

56. Al-Asmari AL, Siddiqui YM, Athar MDT, Al-Buraidi A, Al-Eid AS, Horaib GB Antimicrobial activity of aqueous and organic extracts of a Saudi medicinal plant: Rumex nervosus. J Pharm Bioallied Sci. 2015;7(4):300-3.

57. Getie M, Gebre-Mariam T, Rietz R, Höhne C, Huschka C, Schmidtke M, Abate A, Neubert RHH. Evaluation of the anti-microbial and anti-inflammatory activities of the medicinal plants Dodonaea viscosa, Rumex nervosus and Rumex abyssinicus. Fitoterapia. 2003;74:139-43.

58. Alwashli A, Al Sobarry M, Cherrah Y, Alaoui K. Toxicité aiguë et activité analgésique de l'extrait méthanolique de Rumex nervosus Vahl. Phytotherapie. 2012;10(5):7-9.

59. Demirezer LO. Comparison of two Rumex species with spectrophotometric method and chromatographic identification with regard to anthraquinone derivatives. Planta Med. 1993;59:630.

60. Al-Naqeb G. Antioxidant and antibacterial activities of some Yemeni medicinal plants. Int J Herbal Med. 2015;3(3):6-11.

61. Kasimala MB, Tukue M, Ermias R. Phytochemical screening and antibacterial activity of two common terresterial medicinal plants Ruta chalepensis and Rumex nervosus. Bali Med J. 2014:3(3):116-21.

62. Vasas A, Orbán-Gyapai $\mathrm{O}$, Hohmann J. The genus Rumex: review of traditional uses, phytochemistry and pharmacology. J Ethnopharmacol. 2015;175:198-228.

63. Al-Sunafi SM. Pharmacognostical study of Rumex nervosus Vahl. family (Polygonaceae) growing in Yemen. Eygept: Cairo University; 2016.

64. Tawfika K, Al-Barazib M, Bashirb M, Al-Marzouq W, AlSoufib R, Kharsab H. A comparative study of antioxidant activities of ziziphus and colocynth from Saudi Arabia deserts and proposed pharmaceutical products. IRJPAS. 2015 5(3):8-13.

65. Farooqi A. Plants of Quraan. Lucknow: Sidrah Publishers; 1997. p. 65-74.

66. Ads EN, Rajendrasozhan S, Hassan SI, Sharawy SMS, Humaidi JR. Phytochemical, antimicrobial and cytotoxic evaluation of Ziziphus spinachristi (L.) stem bark. Biomed Res- India. 2017:28(15):6646-53.

67. Abdel-Zaher AO, Salim SY, Assaf MH, Abdel-Hady RH. Antidiabetic activity and toxicity of Zizyphus spina-christi leaves. J Ethnopharmacol. 2005:101:129-38.

68. Alzahrani F, Al-Shaebi EM, Dkhil MA, Al-Quraishy S. In vivo anti-eimeria and in vitro anthelmintic activity of Ziziphus spina-christi leaf extracts. Pak J Zool. 2016:48(2):409-13.

69. Adzu B, Amos S, Amizan MB, Gamaniel K. Evaluation of the antidiarrhoeal effects of Zizyphus spina-christi stem bark in rats. Acta Trop. 2003:87:245-50. 
70. Adzu B, Amos S, Wambebe C, Gamaniel K. Antinociceptive activity of Zizyphus spina-christi root bark extract. Fitoterapia. 2001;72:344-50.

71. Adzu B, Amos S, Dzarma S, Wambebe C, Gamaniel K. Effect of Zizyphus spina-christi Willd aqueous extract on the central nervous system in mice. J Ethnopharmacol. 2001;79:13-6.

72. Al-Ghamdi AAM, Shahat AA. Antioxidant, hypoglycemic and anti-diabetic activities of Ziziphus spina-christi (L) Willd (Rhamnacae) leaf extract. Trop J Pharm Res. 2017;16(11):2601-10.

73. Mohammed GT, Yesufu HB, Khan IZ, Abdulrahman FI. Effects of aqueous and ethanol extracts of the stem bark of Zizyphus spina-christi L. on isolated rabbit jejunum. J Pharm Biores. 2012;9:14-9.

74. Ikram M, Tomlinson H. Chemical constituents of Zizyphus spina-christi. Planta Med. 1976;29:289-91.

75. Shah AH, Ageel AM, Tariq M, Mossa JS, Al-Yahya MA. Chemical constituents of the stem bark of Zizyphus spina-christi. Fitoterapia. 1986;LVII:452-4.

76. Glombitza KW, Mahran GH, Mirhom YW, Michel CG, Motawi TK. Hypoglycemic and antihypoglycemic effect of Zizyphus spina-christi. Planta Med. 1994;60:244-7.

77. Mahran GH, Glombitza KW, Mirhom YW, Harmann R, Michel CG. Noval saponins from Zizyphus spina-christi growing in Eygpt. Planta Med. 1996;62:160-5.

78. Shahat AA, Pieters L, Apers S, Nazeif NM, Abdel-Azim NS, Berghe DV, Vlietinck AJ. Chemical and biological investigations on Zizyphus spina-christi. L Phytother Res. 2001;15:593-7.

Ready to submit your research? Choose BMC and benefit from:

- fast, convenient online submission

- thorough peer review by experienced researchers in your field

- rapid publication on acceptance

- support for research data, including large and complex data types

- gold Open Access which fosters wider collaboration and increased citations

- maximum visibility for your research: over $100 \mathrm{M}$ website views per year

At BMC, research is always in progress.

Learn more biomedcentral.com/submissions 